\title{
Molecular pathways supporting the proliferation staging of malignant melanoma (Review)
}

\author{
PASCALE QUATRESOOZ, GERALD E. PIERARD, CLAUDINE PIERARD-FRANCHIMONT \\ and THE MOSAN STUDY GROUP OF PIGMENTED TUMORS
}

Department of Dermatopathology, University Hospital of Liège, Liège, Belgium

Received March 4, 2009; Accepted May 14, 2009

DOI: 10.3892/ijmm_00000232

\begin{abstract}
The clinical diagnosis of cutaneous melanoma always calls for histological confirmation. In addition to the recognition of the classic aspects of the neoplasm, immunohistochemistry is determinant, in particular in the assessment of the size of the replicative compartment. Generally, the proliferation rate is indicative of the neoplastic progression and is related to the clinical growth rate of the neoplasm. It allows to distinguish high risk melanomas showing a high growth rate from those of lower malignancy associated with a restricted growth rate. In melanoma, the recruitment and progression of neoplastic cells in the cell cycle of proliferation have lost some of their controls that are normally processed by a series of key regulatory molecules. In addition, the apoptotic pathway counteracting any hyperproliferative activity is released of the dependency of specific regulated molecular mechanisms. This review summarizes the current knowledge on key molecular components involved in the deregulation of the growth fraction, cell proliferation and apoptosis in melanocytic neoplasms. The implication of cyclins and of the mitogen-activated protein kinase pathways are scrutinized. The involvement of neoplastic stem cells in the metastatic process is also discussed.
\end{abstract}

\section{Contents}

1. Introduction

2. Growth fraction in melanocytic neoplasms

3. Cyclins in melanocytic neoplasms

4. Mitogen-activated protein kinase pathway in melanocytic neoplasms

Correspondence to: Professor G.E. Piérard, Department of Dermatopathology, University Hospital of Liège, CHU Sart Tilman, B-4000 Liège, Belgium

E-mail: gerald.pierard@ulg.ac.be

Key words: malignant melanoma, cell proliferation, cell differentiation, prognostic factor, apoptosis
5. Stem cells in melanocytic neoplasms

6. Apoptosis in melanocytic neoplasms

7. Conclusion

\section{Introduction}

Human malignant melanoma (MM) is the leading cause of skin cancer death in Caucasians from Western societies $(1,2)$. The traditional classification and staging of sporadic MM rely on the combination of gross clinical and microscopic aspects $(3,4)$. In some instances, the distinction with other atypical melanocytic neoplasms, and the staging of MM may prove to be difficult or uncertain (5). The refinement of such assessments benefit from complementary immunohistochemical investigations. The current progress in molecular biology and morphology brings further information which helps resolve a series of translational investigations (6-15). In particular, it appears that amplifier proliferating neoplastic melanocytes as well as melanocytic stem cells participate in the neoplastic initiation and evolution.

Basically, most MM evolve through the so-called radial growth phase encompassing slow-growing in situ and microinvasive malignancies in which the cure rate is high. Despite a shift toward earlier recognition of melanoma, by the time of diagnosis most MM have evolved to a point, known as vertical growth phase or tumorigenic melanoma, characterized by a rapid growth rate. In these neoplasms, cure is uncertain, and prognosis depends upon certain attributes of the neoplasm and the host.

The MM neoplastic progression appears correlated with the enlargement of the germinative compartment. The proportion of neoplastic cells engaged in the cell cycle of proliferation is increased as well.

Recent advances have been made in the understanding of genetic and epigenetic alterations found in sporadic MM. The altered genes encode regulatory components of the cell cycle. The cell signalling pathways affected by these genes and their biological outcomes support a model in which MM progression requires changes initiating clonal expansion, overcoming cell senescence and reducing apoptosis (16). The issue is the initiation of a fast-growing vertical growth phase in an expansile proliferative pattern with subsequent spreading in an overt metastatic process. This condition contrasts with 
the model of accretive growth found in the radial growth phase.

\section{Growth fraction in melanocytic neoplasms}

There is ample evidence that the size of the MM germinative compartment is indicative of the neoplastic progression $(6,8,17-26)$. A landmark study was performed 25 years ago using incorporations of tritiated thymidine (17). The MM thickness appeared correlated with the proportion of neoplastic cells in the $\mathrm{S}$ phase of proliferation. These findings were confirmed by other observations identifying the proliferation marker Ki-67 which is a nuclear antigen expressed in all active phases of the cell cycle of proliferation $\left(\mathrm{G}_{1}, \mathrm{~S}, \mathrm{G}_{2}\right.$ and $\mathrm{M})$, but absent in the resting phase $\left(\mathrm{G}_{0}\right)$. Ki-67 immunolabeling was positive in $<5 \%$ of nevocytes in most melanocytic nevi, but it commonly increased up to $15 \%$ in melanocytomas and it reached $15-30 \%$ or more in $\mathrm{MM}(3,7,13,14,20,23)$. Accordingly, there are two main clinical applications for using proliferation markers in this field, namely for distinguishing melanocytic nevi from MM, and for estimating the clinical prognosis in MM patients (10,23-26).

A stochastic relationship seems to exist between the MM growth fraction and tumor vascularity (27). However, clinically growth-stunted MM appeared to be typically associated with a poor blood vasculature (28). From these findings, it was inferred that the extent of the blood microvasculature and the size of MM growth fraction were mainly correlated in cases with limited angiogenesis.

The MM growth fraction appears to be influenced by the intratumoral and peritumoral infiltration by Factor XIIIapositive dendrocytes $(21,29)$. There is circumstantial evidence linking the density of Factor XIIIa-positive dendrocytes and a low proliferative rate in MM cells. The biological and molecular mechanisms supporting these findings remain unsettled.

Globally, the findings on MM cell proliferation are in line with the clinical concept distinguishing MM with high and low growth rates, respectively, bearing different prognoses (30). A huge number of primary and secondary molecular changes have been reported in advanced MM compared to melanocytes (16). A primary event in neoplastic progression is clonally inherited, contributing to the eventual malignancy. It occurs independently rather than as a secondary result of some other oncogenic change. Such event is either genetic (gene mutation, deletion, amplification or translocation), or epigenetic (a heritable change other than in the DNA sequence, generally transcriptional modulation by DNA methylation and/or by chromatin alterations such as histone modification). In clonal evolution of cancer, such a primary event initiates a new, more progressed, clone with a growth advantage over its neighbours, or an alternative selective advantage such as migration (16,31). The products of genes subject to recurrent primary clonal alterations in $\mathrm{MM}$ correspond to activated or amplified genes, and conversely to other inactivated or deleted genes. Hundreds of secondary changes have been described in MM (32). Information on MM genomics and epigenetic changes are accumulating (33-36). However, there are still limitations to the interpretations (16). On the one hand, genes have often been tested only for mutations, rather than other events like deletion or amplification, so frequencies of aberration may be underestimated. On the other hand, some studies use only cell lines while others use only uncultured lesional tissues, and the two commonly provides different results.

\section{Cyclins in melanocytic neoplasms}

In the life of cells, there are three optional pathways: cells may continuously proliferate, stay alive without further divisions, or die by apoptosis. The decision as to whether a proliferating cell is to proceed through the cycle is taken at two cardinal points, also referred to as check-points: the commitment to DNA replication at a point termed restriction point and the commitment to mitotic division at the end of $G_{2}$. Throughout $\mathrm{G}_{1}$ phase, growth factors may influence the fate of cells by binding to specific surface receptors, which in turn activate a signalling cascade that regulates the transcription of both immediate and delayed early response genes. Transcription of these genes results in either differentiation or proliferation, the latter being promoted by convergence of receptor-mediated signals on to a 'clockwork' mechanism that ensures an orderly progression through the cell cycle. Once cells have entered $\mathrm{S}$ phase, they become refractory to growth factor-induced stimuli, the subsequent cell cycle events being governed by an intrinsic programme regulating the progression through mitosis. Heteroprotein dimers consisting of a protein kinase catalytic subunit and cyclin as a regulatory protein constitute the basic clockwork of cell cycle progression.

Similarly to many other malignancies, MM cells progress through the deregulation of the mechanisms controlling proliferation and escape from programmed cell death (37). Each step in the cell cycle of proliferation is normally controlled by the expression of a precise set of proteins. A series of cyclin proteins bind and activate cyclin-dependent kinases driving the various phases of the cell cycle (38). The diverse cyclins C, D1 (CCND1 gene product), D2, D3 and E, as well as CDK2, p16 ${ }^{\mathrm{INK} 4 \mathrm{a}}, \mathrm{p} 21^{\mathrm{CIP} 1}$ and $\mathrm{p} 27^{\mathrm{KIP} 1}$ drive the cell cycle of proliferation in its progression from $G_{1}$ to $S$ phase (38). Cyclin A normally regulates the passage from $S$ to $G_{2}$ phase, and cyclin $B$ from $G_{2}$ to mitosis (38).

Cyclin A, B, D1 and D3 are rarely expressed in melanocytic nevi. By contrast, they are commonly present in MM (38). An inverse correlation was reported between cyclin A expression and the disease-free survival in some MM (39). The cyclin B and D1 prognostic relevance remains unsettled in MM. It should, however, be noted that the mutation GG-CCND1 (A8706-CCND1 polymorphism) in peripheral blood cells represents a genetic predisposition to develop MM. Increased cyclin D3 was reported to be associated with early relapse and decreased survival in thin MM but not in thick MM (40). Cyclin E expression appeared to be inversely related with survival of MM patients $(12,41)$.

Cyclin-dependent kinase inhibitors downregulate progress through the cell cycle of proliferation $(12,38)$. For instance, p16 normally inactivates cyclin $\mathrm{D} / \mathrm{cdk} 4$ complexes in most melanocytic nevi (42-44). By contrast, p16 expression is lost in the majority of invasive, recurrent and metastatic MM (42-45). This feature is associated with decreased survival, 
although it is not yet proven to be an independent parameter (38).

The p21 protein inhibits cyclin/cdk complexes and binds to PCNA, thus inhibiting DNA polymerase $\delta o$. It is acknowledged that $\mathrm{p} 21$ is rarely present in melanocytic nevi but it shows increased immunostaining in MM (38). Any relationship between increased p21 immunoreactivity and the disease outcome is unsettled.

The p27 molecule inhibits the cyclin D/cdk4 and cyclin $\mathrm{E} / \mathrm{cdk} 2$ complexes, thus preventing the cell cycle progression from $G_{1}$ to $S$ phase $(46,47)$. A clear distinction is not established in p27 expression between melanocytic nevi and MM. Thicker MM, but not thinner MM, showing <5\% labeling index for p27 might be at increased risk for early relapse. However, the extent of p27 expression has no effect on the overall survival.

The gene encoding p53 protein is the most commonly mutated gene in cancer. The normal wild-type p53 protein is a 53-kDa tumor suppressor protein blocking the cell cycle at $\mathrm{G}_{1}$ and $\mathrm{G}_{2}$ allowing DNA damage can be repaired (48). In addition, it induces the expression of $\mathrm{p} 21$ that contributes to inhibit DNA synthesis. Mutations of the p53 gene lead to an abnormal p53 protein unable to inhibit the cell cycle. As the normal p53 protein has a very short half-life, it is not detected using immunohistochemistry. By contrast, the mutated p53 protein has a longer half-life and is readily disclosed using immunohistochemistry. Accordingly, p53 protein is not revealed in most melanocytic nevi but is present in its mutated form in $25-60 \%$ of MM $(10,49-51)$. Overexpression of p53 has been shown in MM originating from a precursor p53-negative melanocytic nevus (50). Some melanocytomas show about $10 \%$ cell positivity for p53 protein (52). A correlation was reported between p53 expression and the increased MM thickness (53). However, no correlation was evidenced between p53 immunoreactivity and likelihood of metastasis, recurrence and global MM survival.

HDM2 is a $90-\mathrm{kDa}$ zinc finger protein that binds to the transcription activation domain of the p53 gene $(54,55)$. Increased HDM2 immunostaining might be an independent prognostic factor paradoxically associated with decreased recurrence rates and increased survival in MM (55).

\section{Mitogen-activated protein kinase pathway in melanocytic neoplasms}

The mitogenic intrinsic signalling pathway is representative of the mitogen-activated protein kinase (MAPK) cascade, including MAPK kinase (MEK), extracellular signal-regulated protein kinase (ERK), p38 MAPK and Jun NH2-terminal protein kinase (JNK) activation pathways (56). MAPK activation results in the induction of transcription factor AP-1, which regulates the expression of many genes involved in the regulation of cellular growth and differentiation. The MAPK signal transduction pathway is altered in MM (57). The RAS/RAF/MEK/ERK signal transduction pathway is a conserved pathway that regulates cell growth. Signalling through this pathway is elevated in approximately $30 \%$ of human cancers. RAS is mutated in approximately $15 \%$ of human cancers.
MAPK signalling is initiated at the cell membrane, either by receptor tyrosine kinase (RTK) binding ligands, or integrin adhesion to the extracellular matrix. This latter event activates the ras GTPase at the cell membrane inner surface $(58,59)$. GTP-bound ras binds effector proteins, leading to cell proliferation, differentiation, and survival through activation of various signalling pathways (58). It is considered that RAF and phosphatidylinositol 3-kinase (P13K) are the best characterized ras effector proteins.

The RAF protein family represents serine/threonine kinases. It includes three proteins, A-RAF, B-RAF and C-RAF (corresponding to raf-1) coded by unique genes (60-62). RAF is the primary link between ras and the MAPK pathway. It activates the cascade of proliferative or survival signals through phosphorylation of a variety of cytoplasmic targets $(10,63)$. RAF has long been identified as a proto-oncogene (64). B-RAF is mutated in about $7 \%$ of human cancers, but this mutation affects $45-70 \%$ of $\mathrm{MM}$ and some melanocytic nevi as well $(60,65,66)$. This pathway normally regulates cell growth, survival, and invasion. Presence of a B-RAF mutation in MM is statistically associated with some characteristics including a thin neoplasm and a low Ki-67 index (65). Such MM occur more frequently in young adults, on skin areas sporadically exposed to sunlight but heavily exposed during infancy $(29,64)$. By contrast, fast growing $\mathrm{MM}$ rarely contain B-RAF mutations.

Over 50 types of B-RAF mutations are located within the kinase domain, with a single substitution (V600E) accounting for $80 \%(60,67,68)$. The V600E mutant possesses 10.7 -fold kinase activity compared to wild-type B-RAF (60). The presence of activating B-RAF mutations was reported in up to $82 \%$ of melanocytic nevi, suggesting activation of the MAPK pathway is a necessary event for MM development, but it is not sufficient for malignant transformation (65). The activated proteins stimulate constitutive signalling growth of the cells and protect them from apoptosis. When the activity of mutant B-RAF is blocked, cells stop growing and die, suggesting that B-RAF is a valuable and important therapeutic target for cancer treatments. The N-ras and B-RAF mutations observed in MM demonstrate characteristic UV radiation-induced changes, and the target of UV injury leading to such mutations remains unclear $(60,69)$. In addition to MM, B-RAF mutations have been described in a number of other malignancies (57).

A-RAF, B-RAF and C-RAF make up the RAF family of serine/threonine kinases. All RAF family members activate the MAPK pathway, although each isoform possesses a distinct expression profile with unique phosphorylation targets and signalling effects (61). Since most melanocytic nevi possess activating mutations of B-RAF, a single B-RAF mutation is not sufficient to initiate human $\mathrm{MM}$ in vivo (65). Histopathologic assessments suggest that the majority of MM evolve de novo, without a precursor melanocytic lesion (69). In general MM originating from a melanocytic nevus exhibit both a B-RAF mutation or are both negative for the mutation $(70,71)$, supporting a possible evolutionary event. However, a single mutation activating B-RAF is not sufficient to induce malignancy. Rather a single B-RAF mutation appears to be a senescence factor in melanocytes and in melanocytic nevi. Oncogenesis is apparently initiated when a second event 
occurs, for instance the inactivation of the tumor suppressor gene p16.

The genome-wide alterations in DNA copy number, and B-RAF and N-ras mutations in primary human MM suggest the role of B-RAF kinase in MM development and MM heterogeneity (10). Increased B-RAF mutations are found in nodular and superficial spreading MM, compared with acral lentiginous MM and lentigo maligna (72-74). Mucosal MM apparently have infrequent B-RAF mutations (73), suggesting $\mathrm{UV}$-associated MM might evolve from a divergent set of genetic events from UV-protected sites. A direct relationship possibly exists between UV radiation and B-RAF mutation. Indeed, MM with the highest degree of B-RAF mutations were those associated with intermittent sun exposure (72). This relationship reveals a more profound correlation of UV exposure to B-RAF/N-ras mutations and additional genetic events in MM (38). The genome-wide changes in DNA copy number and B-RAF/N-ras mutational status was determined in different types of primary MM. The majority of cutaneous MM developed on intermittent sun-exposed skin showed mutations in B-RAF or N-ras (59 and 22\%, respectively). MM without either mutation often had increased copies of CDK4 or CCND1. Furthermore, no MM with CDK4 amplification manifested concomitant $\mathrm{N}$-ras or B-RAF mutations, or CCND1 amplification. This finding suggests overlapping functions of the MAPK pathway and the CCND1/CDK4 pathways with independent oncogenic functions in each MM. The overall incidence of B-RAF or N-ras mutations was significantly lower in MM developed on chronically sun damaged skin (CSD-MM) and non-exposed sites, with B-RAF and $\mathrm{N}$-ras mutations being mutually exclusive. The MM thickness had no influence on frequency of mutation (B-RAF or N-ras) or amplification (CCND1 or CDK4). Deletion of CDKN2A was prominent in mucosal and acral MM, which also had the greatest incidence of CDK4 amplifications. However, no CDK4 amplifications were present in samples with homozygous CDKN2A deletions. Acral and mucosal MM demonstrated the greatest number of genomic events. In CSD-MM, B-RAF mutations were rare and CCND1 copy gain predominated (75). Conversely, in MM without chronic sun damage, mutant B-RAF and chromosome 10 (site of PTEN) loss were both common. This genetic classification might help to identify MM with high accuracy.

An important link between germline mutations of the melanocortin-1 receptor (MC1R) and B-RAF mutations has been suggested (76). Although MC1R variants were identified as risk factors for MM (77), the precise link to sun exposure and genetic events in primary MM remains unclear. MC1R variant alleles were found to be associated with MM risk, specifically in MM developed outside sun-damaged skin. This risk was associated with neoplasms harbouring B-RAF mutations suggesting that germline events can largely influence genetic events leading to tumorigenesis in response to environmental UV exposures. Thus, the heterogeneous nature of primary $\mathrm{MM}$ and their genetic and environmental basis are being clarified due to a simple subclassification (33).

The enhancement of mitogenic activity in skin cancers, is possibly reflected by the difference of intrinsic mitogenic signalling pathways (78). A signalling pathway involves activation of the MAPK family, whose various members play a complex role in the determination of cell growth. It appears that p38 MAPK is activated by UV irradiation, cytokines, hormones and some stresses such as osmotic shock and heat shock. It has a prognostic value in some malignancies (79).

\section{Stem cells in melanocytic neoplasms}

Cancer stem cells (CSC) have been identified in hematological malignancies and several solid cancers. Similar to physiological stem cells, CSC are capable of self-renewal and differentiation, and have the potential for indefinite proliferation, a function through which they may cause tumor growth. Although conventional anti-cancer treatments might eradicate most malignant cells in a tumor, they are potentially ineffective against chemoresistant $\mathrm{CSC}$, which may ultimately be responsible for recurrence and progression. MM shows tumor heterogeneity, undifferentiated molecular signatures, and increased tumorigenicity of MM subsets with embryonic-like differentiation plasticity. This strongly suggests the presence and involvement of MM stem cells in the initiation and propagation of this malignancy $(15,80-85)$.

\section{Apoptosis in melanocytic neoplasms}

Apoptosis is quite different from necrotic cell death and represents one major mechanism involved in reducing the expansile growth of melanocytic neoplasms. As a functional counterpart of mitosis, apoptosis plays a crucial role and is normally firmly regulated. Apoptosis is deranged in melanocytic neoplasms when the components and regulators of the cellular apoptotic machinery are mutated or present in inappropriate amounts. Some MM cells undergo self-destruction through programmed cell death, i.e. apoptosis (86). In these neoplams, the molecular components of apoptosis include positive (pro-apoptotic) and negative (anti-apoptotic) regulators $(14,87)$. The former include p53, Bid, Noxa, PUMA, Bax, TNF $\alpha$, TRAIL, Fas/FasL, PITSLRE, interferons (IFN), and c-KIT/SCF. The latter anti-apoptotic regulators include Bcl-2, Bcl-X $\mathrm{L}, \mathrm{Mcl}-1, \mathrm{NF}-\kappa \mathrm{B}$, survivin, livin, and ML-LAP $(50,53,83)$. Alternatively, some molecules such as TRAF-2, c-Myc, endothelins, and integrins may have either pro- or anti-apoptotic effects. Some of these molecules are of potential therapeutic use, such as: a) p53, which influences resistance to chemotherapy; b) $\mathrm{Mcl}-1$ and $\mathrm{Bcl}-\mathrm{X}_{\mathrm{L}}$, which can override apoptosis; c) TRAIL, which has selective fatal effects on neoplastic cells; d) downregulated NF- $\mathrm{BB}$ sensitizes cells to TRAIL and TNF; e) PITSLRE kinases, whose alteration appears to result in Fas resistance; f) interferons, which sensitize cells to other factors; and g) survivin that inhibit apoptosis.

Impaired regulation of apoptosis is known to be associated with the development of various forms of cancer. Fas binding to its ligand, Fas ligand (Fas-L) is expressed by MM cells and has been suggested to play a role in MM escape from immune surveillance (87). Apoptotic activity was found to be minimal in MM and moderate in Spitz melanocytomas. In contrast, melanocytic nevi demonstrated significant levels of apoptosis in the deep parts of the tumor. Fas was found to be expressed by all Spitz melanocytomas, most melanocytic nevi and approximately half of the MM. Fas expression was 
also significantly more pronounced in Spitz melanocytoma cells as compared with the two other neoplasms. Fas-L was shown to be more expressed and more frequent in MM cells as compared to nevus cells.

\section{Conclusion}

The links between the clinical evolution, cell proliferation/ apoptosis and key molecular alterations are progressively elucidated in MM. These events represent key factors supporting the distinction of different MM types, including the growth-stunted, the slow-growing accretive growth and the fast-growing expansile proliferative neoplasms.

\section{Acknowledgements}

The members of the Mosan Study Group of Pigmented tumors are Drs J.E. Arrese, G. Blaise, R. Bourguignon, C. Braham, M. Broux, N. Claessens, F. Cornil, M. Damseaux, J.M. Darcis, J. Dehavay, P. Delvoye, C. Devillers, A.L. Fraiture, C. Franchimont, V. Goffin, F. Henry, J.F. Hermanns, T. Lê, M. Lesuisse, B. Letot, O. Martalo, F. Mauhin, A. Nikkels, P. Paquet, G.E. Piérard, P. Quatresooz, A. Rorive, G. Szepetiuk, N. Tassoudji, L. Thirion, E. Uhoda, I. Uhoda, G. Vandenbossche and V. Willemaers. This work was supported by a grant from the 'Fonds d'Investissement de la Recherche Scientifique' of the University Hospital of Liège. No other sources of funding were used to assist in the preparation of this manuscript. The authors have no conflicts of interest that are directly relevant to the content of this review. The authors appreciate the excellent secretarial assistance of Mrs. Ida Leclercq.

\section{References}

1. Jemal A, Siegel R, Ward E, Murray T, Xu J and Thun MJ: Cancer statistics 2007. CA Cancer J Clin 57: 43-66, 2007.

2. Verdecchia A, Francisci S, Brenner H, Gatta G, Micheli A, Mangone L, Kunkler I and EUROCARE-4 WorkingGroup: Recent cancer survival in Europe a 2000-02 period analysis of EUROCARE-4 data. Lancet Oncol 8: 784-796, 2007.

3. Smoller BR: Histologic criteria for diagnosing primary cutaneous malignant melanoma. Mod Pathol 19: 34-40, 2006.

4. Crowson N, Magro CM and Mihm MC: Prognosticators of melanoma, the melanoma report, and the sentinel lymph node. Mod Pathol 19: S71-S87, 2006.

5. Brochez L, Verhaeghe E, Grosshans E, Haneke E, Piérard G, Ruiter D and Naeyaert JM: Inter-observer variation in the histopathological diagnosis of clinically suspicious pigmented skin lesions. J Pathol 196: 459-466, 2002.

6. Alonso SR, Ortiz P, Pollan M, Pérez-Gomez B, Sanchez L, Acuna MJ, Pajares R, Martinez-Tello FJ, Hortelano CM, Piris MA and Rodriguez-Peralto JL: Progression in cutaneous malignant melanoma is associated with distinct expression profiles. A tissue microarray-based study. Am J Pathol 164: 193-203, 2004.

7. Quatresooz P, Arrese JE, Piérard-Franchimont C and Piérard GE: Immunohistochemical aid at risk stratification of melanocytic neoplasms. Int J Oncol 24: 211-216, 2004.

8. Carlson JA, Ross JS, Slominski A, Linette G, Mysliborski J, Hill $\mathbf{J}$ and Mihm M Jr: Molecular diagnostics in melanoma. J Am Acad Dermatol 52: 743-775, 2005.

9. Claessens N, Piérard GE, Piérard-Franchimont C, Arrese JE and Quatresooz P: Immunohistochemical detection of incipient melanoma micrometastases. Relationship with sentinel lymph node involvement. Melanoma Res 15: 107-110, 2005.

10. Fecher LA, Cummings SD, Keefe MJ and Alani RM: Toward a molecular classification of melanoma. J Clin Oncol 25: 1606-1620, 2007.
11. Plaza JA, Suster D and Perez-Montiel D: Expression of immunohistochemical markers in primary and metastatic malignant melanoma: a comparative study in 70 patients using a tissue microarray technique. Appl Immunohistochem Mol Morphol 15: 421-425, 2007.

12. Ohsie SJ, Sarantopoulos GP, Cochran AJ and Binder SW: Immunohistochemical characteristics of melanoma. J Cutan Pathol 35: 433-444, 2008.

13. Quatresooz P, Piérard-Franchimont $\mathrm{C}$ and Piérard GE: Highlighting the immunohistochemical profile of melanocytomas. Oncol Rep 19: 1367-1372, 2008.

14. Quatresooz P, Piérard-Franchimont C, Rorive A, Nizet JL, Piérard GE and the Mosan Study Group of Pigmented Neoplasms: Molecular histology on the diagnostic cutting edge between malignant melanomas and melanocytomas. Exp Rev Dermatol (In press).

15. Schatton T, Murphy GF, Frank NY, Yamaura K, WaagaGasser AM, Gasser M, Zhan Q, Jordan S, Duncan LM, Weishaupt C, Fuhlbrigge RC, Kupper TS, Sayegh MH and Frank MH: Identification of cells initiating human melanomas. Nature 451: 345-349, 2008.

16. Bennett C: How to make a melanoma: what do we know of the primary clonal events? Pigment Cell Melanoma Res 21: 27-38, 2008.

17. Piérard GE, Piérard-Franchimont C, Henry $\mathrm{C}$ and Lapière M: The proliferative activity of cells of malignant melanomas. Am J Dermatopathol 6: S317-S324, 1984.

18. Soyer HP: Ki-67 immunostaining in melanocytic skin tumors. Correlation with histologic parameters. J Cutan Pathol 18: 264-272, 1991.

19. Piérard-Franchimont $C$ and Piérard GE: Karyometry of primary and metastatic malignant melanoma. A correlation with cell proliferation. Am J Dermatopathol 16: 247-252, 1994.

20. Boni R, Doguoglu A, Burg G, Muller B and Dummer R: MIB-1 immunoreactivity correlates with metastatic dissemination in primary thick cutaneous melanoma. J Am Acad Dermatol 35: 416-418, 1996.

21. Piérard-Franchimont C, Arrese JE, Nikkels AF, Al Saleh W, Delvenne P and Piérard GE: Factor XIIIa-positive dermal dendrocytes and proliferative activity of cutaneous cancers. Virchows Arch 429: 43-48, 1996.

22. Talve LAI, Collan YUI and Ekfors TO: Nuclear morphometry, immuno-histochemical staining with Ki-67 antibody and mitotic index in the assessment of proliferative activity and prognosis of primary malignant melanomas of the skin. J Cutan Pathol 23: 335-343, 1996.

23. Sparrow LE, English DR, Taran JM and Heenan PJ: Prognostic significance of MIB-1 proliferative activity in thin melanomas and immunohistochemical analysis of MIB-1 proliferative activity in melanocytic tumors. Am J Dermatopathol 20: 12-16, 1998.

24. Niezabitowski A, Czajecki K, Rys J, Kruczak A, Gruchala A, Wasilewska A, Lackowska B, Sokolowski A and Szklarski W: Prognostic evaluation of cutaneous malignant melanoma: a clinicopathologic and immunohistochemical study. J Surg Oncol 70: 150-160, 1999.

25. Straume O, Sviland L and Akslen LA: Loss of nuclear p16 protein expression correlates with increased tumor cell proliferation (Ki-67) and poor prognosis in patients with vertical growth phase melanoma. Clin Cancer Res 6: 1845-1853, 2000.

26. Frahm SO, Schubert C, Parwaresch R and Rudolp P: High proliferative activity may predict early metastasis of thin melanomas. Hum Pathol 32: 1376-1381, 2001.

27. Piérard GE and Piérard-Franchimont C: Stochastic relationship between the growth fraction and vascularity of thin malignant melanomas. Eur J Cancer 33: 1888-1892, 1997.

28. Piérard-Franchimont C, Henry F, Heymans O and Piérard GE: Vascular retardation in dormant growth-stunted malignant melanomas. Int J Mol Med 4: 403-406, 1999.

29. Quatresooz P, Paquet P, Hermanns-Lê T and Piérard GE: Molecular mapping of Factor XIIIa-enriched dendrocytes in the skin. Int J Mol Med 22: 403-409, 2008.

30. Lipsker D: Growth rate, early detection and prevention of melanoma. Melanoma epidemiology revisited and future challenges. Arch Dermatol 142: 1638-1640, 2006.

31. Hoek KS, Schlegel NC, Brafford P, Sucker A, Ugurel S, Kumar R, Weber BL, Nathanson KL, Phillips DJ, Herlyn M, Schadendorf D and Dummer R: Metastatic potential of melanomas defined by specific gene expression profiles with no BRAF signature. Pigment Cell Res 19: 290-302, 2006. 
32. Hoek KS: DNA microarray analyses of melanoma gene expression: a decade in the mines. Pigment Cell Res 20: 466-484, 2007.

33. Curtin JA, Fridlyand J, Kageshita T, Patel HN, Busam KJ, Kutzner H, Cho KH, Aiba S, Bröcker EB, LeBoit PE, Pinkel D and Bastian BC: Distinct sets of genetic alterations in melanoma. N Engl J Med 353: 2135-2147, 2005.

34. Jönsson G, Dahl C, Staaf J, Sandberg T, Bendahl PO, Ringner M, Guldberg P and Borg A: Genomic profiling of malignant melanoma using tiling-resolution array CGH. Oncogene 26: 4738-4748, 2007

35. Rothhammer $\mathrm{T}$ and Bosserhoff $\mathrm{AK}$ : Epigenetic events in malignant melanoma. Pigment Cell Res 20: 92-111, 2007.

36. Stark M and Hayward N: Genome-wide loss of heterozygosity and copy number analysis in melanoma using high-density singlenucleotide polymorphism arrays. Cancer Res 67: 2632-2642, 2007.

37. Malumbres M and Barbacid M: To cycle or not to cycle: a critical decision in cancer. Nat Rev Cancer 1: 222-231, 2001.

38. Georgieva J, Sinha P and Schadendorf D: Expression of cyclins and cyclin dependent kinases in human benign and malignant melanocytic lesions. J Clin Pathol 54: 229-235, 2001.

39. Florenes VA, Maelandsmo GM, Faye R, Nesland JM and Holm R: Cyclin A expression in superficial spreading malignant melanomas correlates with clinical outcome. J Pathol 195: $530-536,2001$

40. Florenes VA, Faye RS, Maelandsmo GM, Nesland JM and Holm R: Levels of cyclin D1 and D3 in malignant melanoma: deregulated cyclin D3 expression is associated with poor clinical outcome in superficial melanoma. Clin Cancer Res 6: 3614-3620, 2000.

41. Bales ES, Deitrich C, Bandyopadhyay D, Schwahn DJ, Xu X, Didenko V, Leiss P, Cornad N, Pereira-Smith O, Orengo I and Medarno EE: High levels of expression of $\mathrm{p} 27^{\mathrm{KIP} 1}$ and cyclin E in invasive primary malignant melanomas. $\mathrm{J}$ Invest Dermatol 113: 1039-1046, 1999.

42. Talve L, Sauroja I, Collan Y, Punnonen K and Ekfors T: Loss of expression of the $\mathrm{p} 16 \mathrm{I}^{\mathrm{NK} 4} / \mathrm{CDKN} 2$ gene in cutaneous malignant melanoma correlates with tumor cell proliferation and invasive stage. Int J Cancer 74: 255-259, 1997.

43. Pavey SJ, Cummings MC, Whiteman DC, Castellano M, Walsh MD, Gabrielli BG, Green A and Hayward NK: Loss of p16 expression is associated with histological features of melanoma invasion. Melanoma Res 12: 539-547, 2001.

44. Bachmann IM, Straume O and Akslen LA: Altered expression of cell cycle regulators cyclin D1, p14, p16, CDK4 and Rb in nodular melanomas. Int J Oncol 25: 1559-1565, 2004

45. Fearfield LA, Larkin JMG, Rowe A, A'Hern R, Fischer C, Francis N, MacKie R, McCann B, Gore ME and Bunker CB: Expression of p16, CD95L and helix pomatia agglutinin in relapsing and nonrelapsing very thin melanoma. $\mathrm{Br} \mathbf{J}$ Dermatol 156: 440-447, 2007

46. Florenes VA, Maelandsmo GM, Kerbel RS, Slingerland JM, Nesland JM and Holm R: Protein expression of the cell-cycle inhibitor p27 $7^{\mathrm{Kip} 1}$ in malignant melanoma: inverse correlation with disease-free survival. Am J Pathol 153: 305-312, 1998.

47. Ivan D, Diwan AH, Esteva FJ and Prieto VG: Expression of cell cycle inhibitor p27 ${ }^{\mathrm{Kip} 1}$ and its inactivator Jab1 in melanocytic lesions. Mod Pathol 17: 811-818, 2004.

48. Korabiowska M, Betke H, Kellner S, Stachura J and Schauer A: Differential expression of growth arrest, DNA damage genes and tumour suppressor gene p53 in naevi and malignant melanomas. Anticancer Res 7: 3697-3700, 1997.

49. Karjalainen JM, Eskelinen MJ, Kellokoski JK, Reinikainen M, Alhava EM and Kosma VM: P21 $1^{\mathrm{WAF} 1 / \mathrm{CIP} 1}$ expression in stage I cutaneous malignant melanoma: its relationship with p53, cell proliferation and survival. Br J Cancer 79: 895-902, 1999.

50. Rhadi JM: Malignant melanoma arising from nevi, p53, p16, and bcl-2: expression in benign versus malignant components. J Cutan Med Surg 3: 293-297, 1999.

51. Webber BA, Lawson D and Cohen C: Maspin and mutant p53 expression in malignant melanoma and carcinoma: use of tissue microarray. Appl Immunohistochem Mol Morphol 16: 19-23, 2008.

52. Chorny JA, Barr RJ, Kyshtoobayeva A, Jakowatz J and Reed RJ: $\mathrm{Ki}-67$ and p53 expression in minimal deviation melanoma as compared with other nevomelanocytic lesions. Mod Pathol 16: $525-529,2003$

53. Loggini B, Rinaldi I Pingitore R, Cristofani R, Catagna M and Barachini P: Immunohistochemical study of 49 cutaneous melanomas: p53, PCNA, Bcl-2 expression and multidrug resistance. Tumori 87: 179-186, 2001.
54. Polsky D, Bastian BC, Hazan C, Melzer K, Pack J, Houghton A, Busam K, Cordon-Cardo C and Osman I: HDM2 protein overexpression, but not gene amplification, is related to tumorigenesis of cutaneous melanoma. Cancer Res 61: 7642-7646, 2001.

55. Polsky D, Melzer K, Hazan C, Panageas KS, Busam K, Drobnjak M, Kamino H, Spira JG, Kopf AW, Houghton A, Cordon-Cardo C and Osman I: HDM2 protein overexpression and prognosis in primary malignant melanoma. J Natl Cancer Inst 94: 1803-1806, 2002.

56. Johnson G and Lapadat R: Mitogen-activated protein kinase pathways mediated by ERK, JNK, and p38 protein kinases. Science 298: 1911-1912, 2001

57. Ihn H: p38 MAPK inhibitors in dermatology. Expert Rev Dermatol 2: 403-407, 2007.

58. Giehl K: Oncogenic ras in tumour progression and metastasis. Biol Chem 386: 193-205, 2005.

59. Campbell PM and Der CJ: Oncogenic ras and its role in tumor cell invasion and metastasis. Semin Cancer Biol 14: 105-114, 2004.

60. Davies H, Gibnell GR, Cox C, Stephens P, Edkins S, Clegg S, Teague J, Woffendin H, Garnett MJ, Bottomley W, Davis N, Dicks E, Ewing R, Floyd Y, Gray K, Hall S, Hawes R, Hughes J, Kosmidou V, Menzies A, Mould C, Parker A, Stevens C, Watt S, Hooper S, Wilson R, Jayatilake H, Gusterson BA, Cooper C, Shipley J, Hargrave D, Pritchard-Jones K, Maitland N, Chenevix-Trench G, Riggins GJ, Bigner DD, Palmieri G, Cossu A, Flanagan A, Nicholson A, Ho JW, Leung SY, Yuen ST, Weber GL, Seigler HF, Darrow TL, Paterson H, Marais R, Marshall CJ, Wooster R, Stratton MR and Futreal PA: Mutations of the BRAF gene in human cancer. Nature 417: 949-954, 2002.

61. Beeram M, Patnaik A and Rowinsky EK: RAF, a strategic target for therapeutic development against cancer. J Clin Oncol 23: 6771-6790, 2005.

62. Johansson P, Pavey S and Hayward N: Confirmation of a BRAF mutation-associated gene expression signature in melanoma. Pigment Cell Res 20: 216-221, 2007.

63. Marshall CJ: MAP kinase kinase kinase, MAP kinase kinase and MAP kinase. Curr Opin Genet Dev 4: 82-89, 1994.

64. Rapp UR, Goldsborough MD, Mark GE, Bonner TI, Groffen J, Reynolds FH and Stephenson JR: Structure and biological activity of v-raf, a unique oncogene transduced by a retrovirus. Proc Natl Acad Sci USA 80: 4218-4222, 1983.

65. Pollock PM, Harper UL, Hansen KS, Yudt LM, Sark M, Robbins CM, Moses TY, Hostetter G, Wagner U, Kakareka J, Salem G, Phoida T, Heenan P, Duray P, Kallioniemi O, Hayward NK, Trent JM and Meltzer PS: High frequency of BRAF mutations in nevi. Nat Genet 33: 19-20, 2003.

66. Liu W, Kelly JW, Trivett M, Murray WK, Dowling JP, Wolfe R, Mason G, Magee J, Angel C, Dobrovic A and McArthur GA: Distinct clinical and pathological features are associated with BRAF mutation in primary melanoma. J Invest Dermatol 127: 900-905, 2007.

67. Pollock PM and Meltzer PS: A genome-based strategy uncovers frequent BRAF mutations in melanoma. Cancer Cell 2: 5-7, 2002.

68. Brose MS, Volpe P, Feldman M, Kumar M, Rishi I, Gerrero R, Einhorn E, Herlyn M, Minna J, Nicholson A, Roth JA, Albelda SM, Davies H, Cox C, Brignell G, Stephens P, Futreal PA, Wooster R, Stratton MR and Weber BL: BRAF and RAS mutations in human lung cancer and melanoma. Cancer Res 62: 6997-7000, 2002.

69. Brozyna A, Zbytek B, Granese J, Carlson JA, Ross J and Slominski A: Mechanism of UV-related carcinogenesis and its contribution to nevi/melanoma. Expert Rev Dermatol 2: 451-469, 2007.

70. Bevona C, Goggins W, Quinn T, Fullerton J and Tsao H: Cutaneous melanomas associated with nevi. Arch Dermatol 139: 1620-1624, 2003.

71. Yazdi AS, Palmedo G, Flaig MJ, Puchta U, Reckwerth A, Rütten A, Mentzel T, Hügel H, Hantschke M, SchmidWendtner MH, Kutzner H and Sander CA: Mutations of the BRAF gene in benign and malignant melanocytic lesions. J Invest Dermatol 121: 1160-1162, 2003.

72. Maldonado JL, Fridlyand J, Patel H, Jain AN, Busam K, Kageshita T, Ono T, Albertson DG, Pinkel D and Bastian BC: Determinants of BRAF mutations in primary melanomas. J Natl Cancer Inst 95: 1878-1890, 2003.

73. Houben R, Becker JC, Kappel A, Terheyden P, Bröcker EB, Goetz R and Rapp UR: Constitutive activation of the ras-raf signalling pathway in metastatic melanoma is associated with poor prognosis. J Carcinog 3: 6, 2004 
74. Lang J and MacKie RM: Prevalence of exon 15 BRAF mutations in primary melanoma of the superficial spreading, nodular, acral and lentigo maligna subtypes. J Invest Dermatol 125: $575-579,2005$.

75. Cohen Y, Rosenbaum E, Begum S, Goldenberg D, Esche C, Lavie O, Sidransky D and Westra WH: Exon 15 BRAF mutations are uncommon in melanomas arising in non sun-exposed sites. Clin Cancer Res 15: 3444-3447, 2004.

76. Landi MT, Bauer J, Pfeiffer RM, Elder DE, Hulley B, Minghetti P, Calista D, Kantesky PA, Pinkel D and Bastian BC: MC1R germline variants confer risk for BRAF-mutant melanoma. Science 313: 521-522, 2006.

77. Pho L, Grossman D and Leachman SA: Melanoma genetics: a review of genetic factors and clinical phenotypes in familial melanoma. Curr Opin Oncol 18: 173-179, 2006.

78. Lin N, Urabe K, Moroi Y, Uchi H, Nakahara T, Dainichi T, Kokuba H, Tu Y and Furue M: Overexpression of phosphorylated-STAT3 and phosphorylated-ERK protein in dermatofibrosarcoma protuberans. Eur J Dermatol 16: 262-265, 2006.

79. Esteva FJ, Sahin AA, Smith TL, Yang Y, Pusztai L, Nahta R, Buchholz TA, Buzdar AU, Hortobagyi GN and Bacus SS: Prognostic significance of phosphorylated P38 mitogen-activated protein kinase and HER-2 expression in lymph node-positive breast carcinoma. Cancer 100: 499-506, 2004.
80. Fang D, Nguyen TK, Leishear K, Finko R, Kulp AN, Hotz S, van Belle PA, Xu X, Elder DE and Herlyn M: A tumorigenic subpopulation with stem cell properties in melanomas. Cancer Res 65: 9328-9337, 2005.

81. Grichnik JM, Burch JA, Schulteis RD, Shan S, Liu J, Darrow TL, Vervaert CE and Seigler HF: Melanoma, a tumor based on a mutant stem cell? J Invest Dermatol 126: 142-153, 2006.

82. Buac K and Pavan WJ: Stem cells of the melanocyte lineage. Cancer Biomark 3: 203-209, 2007.

83. Klein WM, Wu BP, Zhao S, Wu H, Klein-Szanto AJ and Tahan SR: Increased expression of stem cell markers in malignant melanoma. Mod Pathol 20: 102-107, 2007.

84. Schatton T and Franck MH: Cancer stem cells and human malignant melanoma. Pigment Cell Melanoma Res 21: 39-55, 2007.

85. Rappa G, Fodstad O and Lorico A: The stem cell-associated antigen CD133 (Prominin-1) is a molecular therapeutic target for metastatic melanoma. Stem Cells 26: 2008-3017, 2008.

86. Hussein M, Haemel A and Wood ES: Apoptosis and melanoma: molecular mechanisms. J Pathol 199: 275-288, 2003.

87. Sprecher E, Bergman R, Meilick A, Kerner H, Manov L, Reiter I, Shafer Y, Maor G and Friedman-Birnbaum R: Apoptosis, Fas and Fas-ligand expression in melanocytic tumors. J Cutan Pathol 26: 72-77, 1999. 